\title{
Yeni Kamu İşletmeciliği Paradigmasının Türk Kamu Bürokrasisinde Kamu Personeli İstihdam Şekilleri Üzerine Etkileri
}

The Effects of New Public Management Paradigm on the Public Personnel Employment Types in Turkish Public Bureaucracy

\section{Fatma AKAR}

YL Ö̆rencisi, Mehmet Akif Ersoy Üniversitesi, SBE, Siyaset Bilimi ve Kamu Yönetimi A.B.D., fatmaakar.sdu@gmail.com https://orcid.org/0000-0002-5432-0304
Makale Başvuru Tarihi: 20.12.2018

Makale Kabul Tarihi: 14.01.2019

Makale Türü: Araştırma Makalesi

\section{Anahtar \\ Kelimeler: \\ Geleneksel \\ Anlayış,}

İşletmeci Anlayış,

Kamu Personeli,

Istihdam,

Keywords:
Traditional
Understanding,
Operator
Understanding,
Public Personnel,
Employment,

\section{ÖZET}

Türk kamu bürokrasisi uzun yıllar geleneksel kamu yönetimi anlayışının etkisinde kalmıştır. Geleneksel kamu yönetimin hızla değișen ekonomik, toplumsal ve siyasal gelişmelere ayak uyduramaması nedeniyle, Türk kamu bürokrasisinde değişikliğe gidilme ihtiyacı ortaya çıkmıştır. Yeni kamu iş̧letmeciliği paradigması ülkemizde 1980'li yıllardan itibaren uygulanmaya başlamış ve bu anlayış bütün ülkeleri olduğu gibi Türk kamu bürokrasisini de etkilemiştir. Bu paradigma değişimiyle, Türk kamu bürokrasisinde ve kamu personel istihdamında önemli reformlar yaşanmış, istihdam şekilleri büyük ölçüde değişmiştir. Memurluğun yanında sözleşmeli personel ve geçici personel uygulamaları büyük ölçüde ön plana çıkmıştır.

Çalı̧̧manın ana konusu olan personel reform sürecinde ortaya çıkan istihdam şekilleri de işletmecilik anlayışıyla birlikte değişmiştir. Kamu yönetiminde siyasallaşma, kayırmacılık, yolsuzluk ve rüşvet gibi etkenler istihdam şekillerinin oluşması sürecini büyük ölçüde etkilemiştir. Çalışmanın amacı, Türk kamu bürokrasisinde geleneksel yönetim anlayışından işletmecilik anlayışına geçiş sürecini ve bu süreçte işletmecilik anlayışının Türk kamu bürokrasisine etkilerini incelemektir. Başka bir deyişle, araştırmada yeni kamu işletmeciliği anlayışının personel istihdam şekilleri üzerine yapmış olduğu etkilerin analiz edilmesi amaçlanmaktadır.

\section{ABSTRACT}

The Turkish public bureaucracy has been under the influence of traditional public administration perceptive for many years. Due to the fact that traditional public administration cannot keep up with the rapidly changing economic, social and political developments, there has been a need to change the Turkish public bureaucracy. The new public management paradigm started to be implemented in our country since the 1980s, and this perceptive has affected the Turkish public bureaucracy as well as all countries. With this paradigm shift, Important reforms were experienced in the Turkish public bureaucracy and in the employment of public personnel, forms of employment have changed drastically. Besides civil servant, contracted personnel and temporary personnel applications have come to the fore.

The main subject of the study, the forms of employment in the personnel reform process has also changed with the management perceptive. Factors such as politicization, favoritism, corruption and bribery in public administration have greatly affected the process of formation of forms of employment. The aim of the study is to examine the transition process from traditional management perceptive to management perceptive in Turkish public bureaucracy and the effects of management perceptive on Turkish public bureaucracy in this process. In other words, In other words, it is aimed to analyze the effects of the new public management perceptive on the forms of personnel employment. 


\section{GIRISş}

Türk kamu bürokrasisi uzun yıllar geleneksel kamu yönetimi anlayışının etkisine maruz kalmıştır. Geleneksel yönetim anlayışı Frederick Taylor, Wodroow Wilson gibi düşünürlerden etkilenmiş ama esas olarak Max Weber'in bürokrasi teorisine göre örgütlenmişlerdir. Weber'in bürokrasi anlayışı katı bir hiyerarşiye, merkeziyetçiliğe, kamusal mal ve hizmetlerinin üretiminde doğrudan devlet elinin olmasına dayanmaktadır. Türk kamu bürokrasisi de geleneksel yönetimin etkisinde kalarak uzun yıllar aşırı merkeziyetçi ve kırtasiyeci bir niteliğe bürünmüştür. Geleneksel yönetimin hızla değişen ekonomik, toplumsal ve siyasal etkenlere karşı ayak uyduramaması nedeniyle yönetimde değişikliğe gidilmesi ihtiyacı doğmuştur. Geleneksel yönetim anlayışının eksikliklerini gidermek ve aksayan yönlerini düzeltmek amacıyla bir tepki olarak yeni kamu işletmeciliği anlayışı ortaya çıkmıştır. Yeni kamu işletmeciliği anlayışı 1980'li yıllardan itibaren uygulanmaya başlamış ve bu anlayış bütün ülkeleri olduğu gibi Türk bürokrasisini de etkilemişsir.

Geleneksel yönetimden işletmecilik anlayışına geçiş sürecinde birçok faktör etkili olmuştur. Bunlardan en önemlisi küreselleşen dünya ile birlikte değişen ekonomik koşullar, siyasi koşullar, geleneksel kamu yönetimine getirilen eleştiriler ve yeni Sağ düşüncesidir. Yeni Sağ düşüncesi özel sektörü öven, kamu sektörünü yeren bir anlayıştır. Buna bağlı olarak Yeni kamu işletmeciliği anlayışının oluşumuna da büyük ölçüde yön vermiştir. Yeni kamu işletmeciliği anlayışının en belirgin özelliği, özel sektör yönetim anlayışının kamu sektörüne aktarılmasıdır. Kamuda işletmecilik anlayışının uygulanmasıyla birlikte hizmetlerde etkinlik, verimlilik ve kalitenin arttırılması hedeflenmiştir. Özel sektördeki anlayışın kamu sektörüne aktarılmasıyla daha esnek ve katılımcı bir yönetim sağlamaya çalışılmıştır.

Çalışmamızın ana konusu olan personel istihdamı şekilleri de işletmecilik anlayışıyla birlikte değişmiştir. Bu istihdam şekillerinin oluşturulması belirli bir sürece bağlanmıştır. Kamuda yaşanan siyasallaşma, kayırmacılık, yolsuzluk ve rüşvet gibi etkenler yeni istihdam şekillerinin ortaya çıkışında büyük rol oynamıştır. Yeni kamu işletmeciliği anlayışı ile birlikte memurluk statüsü esnek hale getirilmiş ve memurla hemen hemen aynı işi yapan fakat aynı statüde olmayan istihdam şekilleri getirilmiştir.

Çalışmanın amacı, kamu personel yönetiminin tanımı, kapsamı ve tarihçesini incelemek, Türk kamu bürokrasisinde geleneksel yönetimden işletmecilik yönetimine geçiş sürecini, bu süreçte işletmecilik anlayışının Türk kamu bürokrasisine etkilerini, kamu personel sürecinde yeniden yapılanma gerektiren sebepleri ve yeni kamu işletmeciliği anlayışının personel istihdamına yapmış olduğu etkileri değerlendirmektir. Bütün bunlar sonucunda da 'Yeni kamu işletmeciliği anlayışı Türk kamu yönetimi içerisinde bulunan personel istihdam şekillerini ne ölçüde etkilemiştir?', sorusuna yanıt bulmaktır. Araştırmamızın sonucuna literatür taraması yöntemi kullanılarak ulaşılmaktadır.

\section{KAMU PERSONEL YÖNETIMININ TANIMI VE KAPSAMI}

Personel sözcüğü, Fransızca bir kelime olan "personnel" sözcüğünden esinlenerek ortaya çıkmış ve Türkçemize girmiştir (Kayar, 2015:1). Buna bağlı olarak da personel 'Bir hizmet veya kuruluşun görevlileri, bir işyerinde çalışanların tümü, devlet ve diğer kamu kuruluşlarında çalışan, etkinliğe çeşitli görevleriyle katılan gerçek kişiler'” olarak tanımlanabilmektedir (http://www.tdk.gov.tr/). Yine benzer bir şekilde personel yönetimi, bir örgüt içerisinde örgüt çalışanlarının ihtiyaç duyduğu kadar insan kaynağını sağlamanın ve sağlanan bu kaynaktan en verimli ve en etkin bir biçimde yararlanabilmenin yöntemini gösteren bir sıkı düzen olarak da tanımlanabilir (Kayar, 2011:2).

Kamu ve özel sektör çalışanları farklı biçimde adlandırılmaktadırlar. Kamu sektöründe çalışanlar, "memur, sözleşmeli personel, geçici personel ve işçi (geçici veya kadrolu işçi)" olarak istihdam edilmektedirler. Özel sektörde çalışanlar ise, "büro hizmetlerinde çalışanlar (beyaz yakalılar ya da beden gücü ile çalışan (mavi yakalılar)" olarak adlandırılmaktadırlar (Kayar, 2011:4-5).

Personel yönetimi, iki taraflı bir amacı gerçekleştirmek görüşündedir. Bu görüşe göre, örgüt içerisinde bulunan insan kaynağı öyle bir şekilde kullanılmalıdır ki, bunun sonucunda işveren örgütü oluşturan kişi ve grupların sahip olduğu yeteneklerden en yüksek faydayı sağlayabilme imkânına sahip olabilmelidir. Personel de yaptı̆̆ iş ve hizmetten maksimum düzeyde bir çıkar elde edebilmeli ve kendisine psikolojik doyum sağlayabilmelidir. Personel yönetimi ise, bu karşılıklı amacını ortaya koyabilmek için insan kaynağı ile "yararlanma, isteklendirme ve koruma" olarak üç farklı açıdan ilgilenmektedir. İnsan kaynağından yararlanma, sahip olunan insan gücünün ihtiyaç doğrultusunda aranarak bulunmas1, aranıp bulunan insan gücünün yetiştirilmesi, 
yetiştirilen insan gücünün değerlendirilmesi ve değerlendirerek yükseltilmesi, görev tanımında ve görev yerinde değişiklik yapılması ve son olarak da işine son verilmesi gibi teknik unsurları içermektedir. İsteklendirme, iş ile işi yapan arasındaki ahenksizliklerin ortadan kaldırılması ve bireyin örgütün başarısını arttırmak için katkıda bulunan çeşitli önlemleri içermektedir. Koruma fonksiyonu ise, en başta çalışma şartlarının iyileştirilmesini, iş güvenliği gibi insan kaynă̆ının toplumdaki sosyal varlığını korumak adına alınan her türlü önlemleri içermektedir (Tutum, 1979:1).

Kamu personel yönetimi, devletin bütün kamu hizmetlerini yürütmekte yükümlü olduğu ve bu hizmet yükümlülüğünü yerine getiren kamuda vazifeli sayılan görevlilerin bağlı bulunduğu uygulamaları ve temel kurallardan oluşan bir bütünü ifade etmektedir (Eroğlu, 2010:226). Kamu personel yönetiminde özellikle kamu hizmetlerini yerine getirebilecek personel düzeninin mevcut varlığı, hizmetlerin yürütülmesi için gerekli nitelikte ve gerekli sayıda personel sağlanması, kamu hizmetini yerine getirebilecek uygun becerilere ve bilgiye sahip nitelikte personel yetiştirilmesi gibi konular göz önünde bulundurulduğunda kamu personel yönetiminin gittikçe öneminin arttı̆̆g görülmektedir (Güler, 2005:45,52).

\section{KAMU PERSONEL YÖNETIMININ TARIHSEL GELIŞSiMI}

Modern açıdan personel yönetiminin tarihsel gelişimine bakıldığı zaman bu sürecin çok yakın dönemlere denk geldiği ve bilimsel açıdan bir personel yönetimi olgusunun yaklaşık olarak 1940'lı yıllarda başladığı görülmektedir. Buna karşılık ise, personele yönelik sorunların değer kazanması, bu sorunların yöneticiler tarafından dikkate alınması ise çok daha geri dönemlere uzanmaktadır (Yalçın, 2002:3).

Ülkemizde personel yönetimi anlayışı yönetim anlayışı ile büyük ölçüde benzerlik göstermektedir. Bilindiği üzere yönetim anlayışı Osmanlı Devleti dönemine kadar uzanmaktadır ve Osmanlı Devleti de bünyesinde güçlü bir bürokrasi barındırmaktadır. Personel yönetimi anlayışı da Osmanlı Devleti'nde gelişen 'merkeziyetçi, mevzuatçı, gelenekçi ve memurluğa dayalı" yönetim sisteminden büyük ölçüde etkilenmiştir (Tutum, 1979:15).

Cumhuriyet'in kuruluşundan günümüze gelinceye değin, devletin işlemesini sağlamak amaciyla modern bir personel sistemi ortaya çıarma çabaları görülmüştür (Kayar, 2011:9). Cumhuriyetle birlikte ise personel yönetiminde liyakat ve kariyer ilkelerinin uygulanmasıyla ilgili çabalar yoğunluk göstermiş̧ir (Tutum, 1979:15). Cumhuriyet döneminde oluşmuş olan kamu personel düzeninin belli başl1 özellikleri (Kayar, 2011:9):

- "Memurluk rejiminin yasalarla düzenlenmesi geleneği

- 'Kamu personel sisteminin yargısal denetiminin Fransa'dan esinlenerek özel kurallara bağlanmasl',

- 'Personel sisteminin genel yönetiminden sorumlu merkezi bir personel dairesi yaratmaya çalışarak kurumsal yapı oluşturma çabaları"' ş̧eklinde özetlenebilmektedir.

Cumhuriyet dönemindeki personel yönetiminin özellikleri dikkate alınarak, Türkiye'de memurluk düzeni o dönemlerde hukuki yönden güvence barındıran, ekonomik bakımdan çekicilik uyandıran, kendi örgütü içerisinde disiplinli, halkla olan ilişkilerinde otoriter bir tavır sergileyen ve görevde yükselmede kıdeme dayalı, biçimsel ve ağır işleyen bir sistem olarak görünüm kazanmıştır. Ancak bunun sonrasında da İkinci Dünya Savaşı'yla birlikte ortaya çıkan gelişmeler, Cumhuriyet Dönemi'ndeki personel yönetiminin sahip olduğu özellikleri büyük ölçüde etkilemiş ve yeni özellikler kazandırmıştır. Bugün hala kamu personel yönetimi, daha çă̆daş nitelikler elde etme yolunda büyük çabalar göstermektedir (Tutum, 1979:17). 


\section{KAMU PERSONELINIIN ÖZEL SEKTÖR PERSONELINDEN FARKI}

Kamu personeli ve özel sektör personelinin belirli bir amaçlarının olması, bu amaçların gerçekleştirilmesinde birbirine benzer araçların kullanılması ve çalışanların eğitilmesi gibi ortak yönleri bulunmaktadır. Ancak bu ortak yönler dışında kamu ve özel sektör personeli arasında birçok farklılık da görülmektedir. Bu farklılıklar şu şekilde sıralanmaktadır:

- Kamu personelinin göreve alınmaları, hak ve yükümlülükleri, çalışma koşulları, işten çıkarılmaları yasalarla düzenlenmiştir. Yani kamu personeli yasa yoğunluklu bir alandır. Özel kesim personel yönetiminde de yasalar bulunmaktadır, ancak bu yasalar oldukça az ve ayrıntısı olmayan yasalardır.

- Kamu personelinin amacı kamu yararıdır, özel yönetim çalışanlarının amacı ise kar elde etmektir.

- Kamu personeli amacını gerçekleştirirken kamu gücünden faydalanmaktadır, karşı tarafın isteği olsa bile tek taraflı karar alabilmekte ve kararları uygulayabilmektedir. Özel yönetim personelinin ilişkileri ise hukuksal anlamda eşitlik prensibine dayanmaktadır.

- Özel kesimin personeli kamu personeline nazaran daha fazla serbestliğe ve içinde bulundukları örgütün ihtiyaçlarına daha fazla çözüm bulabilme imkanına sahip olmaktadırlar.

- Kamu personeli ve özel yönetim personeli arasındaki bir fark da sorumluluk bağlamında meydana gelmektedir. Kamu personelinin sorumluluğu sadece bütçe kurallarına veya yasalara uymadığı taktirde meydana çıkarken, özel sektör personelinin en önemli sorumluluk sebebi işlerin kötü ve başarısız bir şekilde yürümesidir.

- Kamu personelinin eylemleri çoğunlukla tekelcidir, bu yüzden de personeller arasında yarışma kuralları işlememektedir. Fakat özel sektör personeli arasında yarışma kuralları görülebilmektedir.

- Özel sektör personeli, kamu personelinden daha çok bağımsızlığa sahip olmaktadır, çünkü kamu personeli kamusal bir çerçeve içerisinde görevini yürütmek zorundadır. Yasalar ve birtakım düzenleyici işlemler kamu personelinin hareket alanine sınırlı hale getirmektedir. Bunun yanı sıra, kamu personeli hem yasama hem de yürütme organlarının denetimine tabi tutulabilmektedir.

- Özel yönetimler, personellerini yönetirken ayrıcalıklar getirebilme hususunda daha özgürce hareket edebilmekte, ancak kamu yönetiminin personeline tanıdığı bir ayrıcalık bulunmamaktadır. Çünkü özel yönetimin kamudan daha fazla personeline ücret ödeme imkanı bulunmaktadır (Turan, 2016:61-62).

- Kamu personelinin işe alımında arz ve talep ilkeleri söz konusu olmamaktadır. Özel kesimde ise personel alımı arz-talep ilkelerine bağlı olarak gerçekleşmektedir (Can vd., 2009:21).

\section{GELENEKSEL KAMU YÖNETIMI ANLAYIŞINDAN YENI KAMU İŞLETMECİL̇Ğİ ANLAYIŞINA GEÇIŞ SÜRECI}

\subsection{Geleneksel Kamu Yönetimi Anlayışı}

Geleneksel kamu yönetimi zihniyeti, 19. Yüzyıldan 20. Yüzyılın sonlarına kadar Türk kamu yönetiminde egemen olan modelin adıdır (Eryılmaz, 2010:16). Genel olarak bilindiği üzere geleneksel kamu yönetimi zihniyeti, Max Weber'in bürokratik örgütlenme değerlerine dayanan bir anlayıştır ve ülkemizde de uzun yıllar uygulama alanı bularak geniş bir yer edinmiştir (Parlak, 2011:98).

Geleneksel kamu yönetimi zihniyetinin düşünce temelleri, büyük oranda Woodrow Wilson, Frederick Taylor ve Max Weber'in düşünce ve değerlerine dayanır (Eryılmaz, 2010:16). Geleneksel yönetimin bir bilim uğraş1 olması çağrısını ilk olarak Wodroow Wilson, 1887 yılında "The Study Of' yani "'Yönetimin İncelenmesi", isimli makalesiyle yapmıştır (Çevik, 2012:54). Wodroow Wilson 19. Yüzyılın sonlarına doğru yazdığı makalesinde, kamu yönetimi disiplinini siyaset biliminden özerk bir disiplin vaziyetine getirmek amaciyla "siyaset- yönetim ayrıllğ̆ı" ilkesini savunmuştur (Eryılmaz, 2010:16). Taylor ise, getirmiş olduğu yönetim düşüncesiyle bilimselliğin ne kadar önemli bir olgu olduğunu öne çıkarmıştır. Ayrıca öne sürdüğu düşüncenin temellerini de bilimsel yönetim ilkeleri adıyla şu şekilde sıralamıştır:

- Yönetim, yapılacak olan her iş için bir iş bölümü ve bir birim oluşturmalıdır. 
- Yönetim, işçi alırken bilimsel olarak seçmeli, aldığı işe göre eğitmeli ve işçiyi bu doğrultuda geliştirmelidir.

- Yönetim, işçilerin bilimsel yöntemlere uygun olarak çalışmasını sağlamalıdır.

- Yönetim, eşit ve dengeli bir biçimde iş sorumluluğunu yöneticiler ve işçiler arasında paylaştırmalıdır (Çevik, 2012:54-55).

Max Weber ise, bir sosyolog olmasına rağmen yönetim ve siyasi yapı konularında özellikle de bürokrasi konusunda çok önemli açıklamalarda bulunmuştur. Bu gerekçeyle de örgüt teorisi ve geleneksel yönetim denildiği zaman Weber'den bahsedilmemesi mümkün değildir (Çevik, 2012:56). Weber, 'ideal tip bürokrasi'" modelini formüle etmiş ve bu modelin bürokraside en etkili ve en rasyonel örgütlenme şekli olduğuna ilişkin bir düşünce geliştirmiş (Eryılmaz, 2010:16) ve bu ideal tip örgütlenme modelini rasyonellik, etkinlik ve verimlilik temeline dayandırmıştır (Yerli ve Çeçen, 2014:100). Bu bağlamda Weber, bürokrasi konusundaki tartışmalarını toplumdaki üç tip otoriteyle bağlantılı olarak analiz etmiştir. Weber'in öne sürdügü otoritelerin ilki olan karizmatik otorite, bir kişinin olağanüstü karakterine, topluma örnek olan bir karaktere dayanır ve bu otorite geçicidir, er ya da geç başka bir otoriteye dönüşür. İkinci olarak geleneksel otorite, gücü geleneksel olarak elinde tutan ve statik bir yapıya sahip olan bir otorite tipidir. Sonuncusu ve diğer iki otorite tipinden daha üstün konumda olan rasyonel-hukuki otorite ise, normatif kuralların yasallığına inanmayı ve bu kuralları uygulayabilecek emir vermek üzere yetkilendirilmiş kişiler olmasını öngören bir otorite tipidir (Çevik, 2012:5657).

Günümüzde yakın zamana gelinceye kadar hâkim durumda olan geleneksel yönetim anlayışının temel esasları şu şekilde sıralanabilir:

- Geleneksel yönetim anlayışı, Max Weber'in bürokrasi modeline uygun olarak örgütlenmiştir.

- Devletin mal ve hizmet üretiminde doğrudan müdahalesi olmalı ve kendi örgüt eliyle yürütmesi gerekmektedir.

- Kamuda idari ve siyasi işlerin birbirinden bağımsız olması ve ayrılması gerekmektedir.

- Güçlü bir bürokrasi oluşturulması ve çalışanların üst düzey bürokratlara göre işleyen bir nitelik taşıması sağlanmalıdır (Parlak,2011:99).

\subsection{Yeni Kamu İşletmeciliği Anlayışına Geçişi Etkileyen Faktörler}

Yeni kamu işletmeciliği, kamu yönetimi anlayışından kamu işletmeciliği anlayışına doğru meydana gelen değişimin adıdır (Eryılmaz, 2010:18). Yeni kamu yönetimi zihniyeti, 1980'li yıllarda yönetimde uygulama alanı bulmuş ve en çok da İngiltere ve gelişmiş bir ülke olan ABD ile iç içe olan bir kamu yönetimi anlayışıdır (Kesik ve Canpolat, 2011:161). Yeni kamu işletmeciliği anlayışı, 1980 ve 1990'lı yılların başlarında egemen olan geleneksel kamu yönetimi anlayışının getirmiş olduğu yetersizliklere bir tepki olarak doğmuş ve bu anlayışla kamuda yeni bir yönetim tarzı ortaya çıkmıştır (Balc1 vd., 2003:25). Bu anlayışın ortaya çıkışında ve bu değişim sürecinde özel sektördeki yaşanan değişimler, geleneksel kamu yönetimi ve kamu örgütüne yöneltilen eleştiriler, ekonomik değişimler ve Yeni Sağ düşüncesi büyük ölçüde önem taşımaktadır (Eryılmaz, 2010:18).

Yeni kamu işletmeciliği anlayışı ile birlikte kamu yönetiminde uzun yıllar hüküm sürmüş olan katı, hiyerarşik, bürokratik ve merkeziyetçiliğe dayalı olan anlayışın yerini daha esnek, müşteri odaklı ve piyasa temelli bir yönetim yapısı anlayışı almak zorunda kalmıştır (Parlak ve Sobac1, 2008:190). Yeni Sağ akımı, devletin küçültülmesi, vergilerin düşürülmesi, göç karşıtı kampanyalar çıkarılması, piyasa temelli mekanizmaların tercih edilmesi gibi birçok düşünceyi bünyesinde barındıran çok geniş bir terimi kapsamaktadır. Yeni Sağ düşüncesi 'özel sektör iyi, kamu sektörü kötü' düşüncesini taşıdığı için de kamu yönetiminde yönetim anlayışının değişiminde büyük rol oynamıştır (Eryılmaz, 2010:18-19).

Hood, yeni kamu işletmeciliği anlayışının ortaya çıkışında sadece tek bir sebebin bulunmadığını, birden çok faktörün etkili olduğunu açıklamış; bu faktörleri ise, "ekonomik ve mali faktörler", "sosyal faktörler" ve "politik ve ideolojik faktörler" olarak sıralamıştır (Parlak ve Sobacı, 2008:191). Ekonomik ve mali nedenlerin yeni kamu işletmeciliğinin ortaya çıkışında çok önemli bir yeri vardır. Bu önemin sebebi ise, 1970'li yıllarda yaşanan ekonomik bunalım, ekonomik durgunluk ve bu durgunluğun devletin mali yapısını büyük ölçüde tahrip etmesidir (Sobacı, 2014:55). 1973'te yaşanan petrol krizi ve 1970'li yıllarda yaşanan ekonomik bunalım işsizliği 
ve kamu yatırımlarının azalmasını beraberinde getirmiştir. Bütün bunların sonucunda 1979'da görev başına gelen hükümet, kamuda köklü bir reform yapılması gerektiğini savunmuştur. Ekonomik etkenlere bağlı olarak ülkede yaşlı nüfusun artması ve genç nüfusun çeşitli sorunlar yaşaması sosyal etkenlerin de baş göstermesine neden olmuştur (Balcı vd., 2003:30-31). Toplumsal değişim adı verilen bu olayda, insanların kamudan beklediği hizmetlerde farklılıklar olmuş, daha kaliteli ve verimli bir hizmet beklentisi içerisine girmişlerdir. Bu nedenle de vatandaşın müşteri gibi algılandığı bir yönetim anlayışına geçilmek zorunda kalınmıştır (Sobacı, 2014:57). Ekonomik ve sosyal nedenlerden farklı olarak siyasal etkenlerin başında 1980 sonrası yaşananlar büyük rol oynamıştır (Balcı vd., 2003:31). Dünya genelinde yaşanan kötü yönetim uygulamaları (Sobacı, 2014:60), muhafazakâr partilerin yürüttükleri politikalar kaynakların israfına ve hizmetlerin verimsizliğine yol açmıştır (Balcı vd., 2003:32). Dolayısıyla bu süreç, kamu yönetiminde derin ve dinamik yapıdaki bir ideolojik süreci ifade etmektedir (Sobac1, 2014:57).

Kamu kesimindeki bu değişim, bu kesimde çalışan her düzeydeki ve her türdeki yöneticilerin özel sektör yöneticileri gibi davranmalarını ve onlar gibi düşünmelerini öngörmektedir. $\mathrm{Bu}$ nedenle de yeni kamu işletmeciliği anlayışı, kamu kesiminde etkinliğin arttırılmasında bir araç olarak görülmektedir (Acar ve Özgür, 2014:24).

\subsection{Yeni Kamu İşletmeciliği Anlayışı}

Yeni kamu yönetimi anlayışı, 1980'lerde başlamış ve 1990'l y yllarda gelişen bir yönetim düşüncesidir. Yeni kamu yönetimi düşüncesi, devlet hizmetlerinin özel sektör tarafından görülmesi yani özelleştirilmesi, devletin küçültülmesi ya da devletin etkinlik alanının daraltılması anlamına gelir. Bu yönetim anlayışı ile kamunun etkinlik alanı küçülmüş ve yönetim daha etkili ve verimli hale gelmiş olacaktır (Aydın, 2012:289-291).

$\mathrm{Bu}$ anlayış her şeyden önce geleneksel yönetim anlayışının eksikliklerini gidermek ve kusurlarını kapatmaya çalışmıştır (Al, 2002:144). Yeni kamu yönetimi anlayışı geleneksel yönetim anlayışının geniş ölçekli, hiyerarşik bir şekilde örgütlenmiş katı bürokrasisini reddetmiş, âdem-i merkeziyetçi, müşteri merkezli, rekabet ortamı yaratan, tercih imkânı sunan ve daha esnek bir yönetimi değerleri haline getirmiştir. Yeni kamu yönetimi anlayışı, olabildiğince uzmanlaşmaya, daha iyi örgüt performansına, teknik uzmanlığa, başarılı olma yolunda büyük oranda yetki devrine, aktif ölçüm tekniklerine, örgütsel çıktıları uygun bir hale getirmeye ve bütün bu gelişmeleri sağlarken de uygun kültürler geliştirmeye önem vermektedir (Özer, 2005:240-241).

Yeni kamu yönetimi anlayışı,esas olarak bakıldığında temelinde sağlam bir kuramsal dayanağa sahip değildir. $\mathrm{Bu}$ anlayış, yeni bir şey üretmekten daha çok pratik çözümler üretmeyi amaçlayan bir yönetim anlayışını ortaya koymaktadır. Dolayısıyla en çok da, özel sektörün yönetimcilik anlayışını kamu sektörüne uygulayarak kamuda etkinlik ve verimliliği sağlamayı hedeflemektedir (Genç, 2012:34).

Yeni kamu işletmeciliği anlayışı ile birlikte kamu yönetiminde uzun yıllar hüküm sürmüş olan katı, hiyerarşik, bürokratik ve merkeziyetçiliğe dayalı olan anlayışın yerini daha esnek, müşteri odaklı ve piyasa temelli bir yönetim yapısı anlayışı almak zorunda kalmıştır (Parlak ve Sobacı, 2008:190). Kamu kesimindeki bu değişim, bu kesimde çalışan her düzeydeki ve her türdeki yöneticilerin özel sektör yöneticileri gibi davranmalarını ve onlar gibi düşünmelerini öngörmektedir. Bu nedenle de yeni kamu işletmeciliği anlayışı, kamu kesiminde etkinliğin arttırılmasında bir araç olarak görülmektedir (Acar ve Özgür, 2014:24).

Kamu işletmeciliği anlayışının bir faydası vardır ki, bu da geleneksel yönetim anlayışında olduğu gibi, kamu idarecilerinin sorunları daha gerçek bir şekilde anlamasına ve çözmesine yardım etmesidir. Görev başındaki kurumlarda kamu kesiminin faaliyetleri devam etmektedir ve personel istihdamı gerçekleştirilerek çalışmalar halk adına ve halk için yerine getirilmektedir (Hughes, 2014:49).

Bütün bunlara bakılarak yeni kamu işletmeciliği anlayışının temel özellikleri şu şekilde sıralanmaktadır:

- Weber'in bürokrasi modeline karşıdır, esnek bir yönetimi, yumuşak bir alt üst ilişkisini ve yerelleşmeyi önermektedir.

- Devletin etkinlik alanının küçülmesini ve yeni oluşturulacak devletin rolünün değiştirilmesini, katılımcı ve girişimci bir yönetimi, piyasa düzeneklerinin olmasını ve müşteri merkezli olmayı tavsiye etmektedir.

- Hizmette verimliliğe, etkinliğe ve kalitenin önemine vurgu yapmaktadır.

- Yönetimde açıklığı savunmaktadır. Bir tek siyasi otoriteye değil, halka karşı da sorumluluğunu bilen bir yönetimi savunmaktadır (Aydın, 2012:291). 
Yeni kamu işletmeciliği anlayışının olumlu yanları dışında eleştirilen yanları da bulunmaktadır. Bazı bilim adamları yeni kamu işletmeciliği anlayışının, gerek sosyal gerek idari gerekse ekonomik temelli düşünceler hususundaki ortaya koymuş olduğu özelliklerin kamu yönetiminde her zaman geçerli olamayacağı düşüncesini taşımaktadırlar. Yeni kamu işletmeciliği anlayışına göre, kamusal hizmetler özel sektörün sunmuş olduğu hizmetlere kıyasla belirli sınırlar içerisinde kalan niteliklere sahip olmaktadır. Bu durum da, kamu kesimindeki tüketici ve tedarikçi arasındaki ilişkilerin birbirine aykırı olmasından kaynaklanmaktadır. Ayrıca, bu yaklaşımın özelliklerinden biri olan halkın 'müşteri"' olarak görülmesi de doğru bir bakış biçimi olarak görülmemektedir. Çünkü 'müşteri"' ifadesi, bir iş ilişkisinin meydana gelmesini, bu ilişkinin devam ettirilmesini ve iş ilişkisinin bitirilmesinin mümkün olmasını gerektirmektedir. Oysa ki, kamunun öngördügü 'vatandaşlık" kavramı, sürekli yükümlülükleri ve belirli kamu hizmetlerinden faydalanmanın zorunlu olduğu gerektiğini ifade etmektedir. Kamu sektöründe gözle görülebilir amaçlar belirlemek ve bunların ortaya çıkaracağı sonuçları önceden kestirebilmek oldukça zor olmaktadır. Bu nedenle de, yeni kamu işletmeciliği anlayışının, kamu sektörü ile özel sektör arasında bulunan bu yoğun farka önemsiz bir şekilde yaklaşan öngörüleri de geçerli olmamaktadır. Ayrıca bu yaklaşımın ortaya koymuş olduğu etkinlik, verimlilik, planlama gibi bazı kavramlar üzerinde belirli bir görüş birliği sağlanamamış ve bu kavramların kamu sektörü için ne kadar başarılı olup olmadığı henüz saptanamamıştır. Bunun yanı sıra yeni kamu işletmeciliği anlayışı geleneksel kamu yönetimi anlayışının eksikliklerini ortaya koyması, bu eksikliklere bir çözüm üretememesi, sürekli olarak dikkatleri bu eksikliklere çekmesi nedeniyle yetersiz bir anlayış olarak görülmekte ve literatüre bir katkısı olmadığı düşünülmektedir. Yeni kamu işletmeciği yaklaşımının eleştirilen yanlarından biri de "kamu hizmeti" ve "özelleştirme"' söylemlerinden kaynaklanmaktadır. Bu yaklaşım kamu hizmeti kavramına olduğundan daha fazla sinırlama getirmektedir. Yani bu da, kamu hizmetinin piyasa yoluyla hizmete sunulması anlamina gelmektedir. Özelleştirme konusunda ise, üretim birimlerinin özelleştirildiği taktirde ekonomide verimliliği arttıracağı öngörüsü de gerçekçi bulunmamaktadır. Çünkü bu düşünceye destek veren kanıtların umulduğu kadar da güçlü olmadığı düşünülmektedir (Bozlağan ve Demirkaya, 2008:14-16).

Yeni kamu işletmeciliği anlayışının gereklerini büyük ölçüde içinde barındıran personel istihdamıyla ilgili çıkarılmış olan 'Kamu Yönetimi Temel Kanun Tasarısı'” ile kamu görevlilerinin sözleşmeli pozisyona geçirilmesi düşüncesi de, kamu görevlilerinin kazanılmış haklarının kaybedilmesine neden olmaktadır. Çünkü getirilen bu sistemle memurlar himayesiz kalmaktadırlar. Yine bu tasarı sistemiyle getirilmiş olan "performansa göre ücret" düzenlemesi de kamu çalışanları arasında çatışma ve sorunların ortaya çıkmasına neden olmaktadır. Bu durum da toplumsal açıdan bakıldığından huzursuzlukları ortaya çıkarmaktadır. $\mathrm{Bu}$ huzursuzlukların önlenmesi amacıyla da devlet memurlarının sözleşmeli personel statüsüne geçirilmemesi gerekmektedir (Çevikbaş, 2012:26).

\subsection{Yeni Kamu İşletmeciliği Anlayışının Türk Kamu Bürokrasisine Etkileri}

Küresel ilerlemeler ve gelişmeler, özellikle 1980'li yıllardan beri kamu bürokrasilerini değiştirmiş ve baskısı altına almıştır (Kalağan, 2010:145). Türk kamu bürokrasisi de kısa zamanda değişimin etkisi altına girmiş, yeni kamu işletmeciliği anlayışı kamu bürokrasisindeki uygulamaları ve yapıları derinden etkilemiştir (Acar ve Özgür, 2014:28).

Türk toplumu 1980'li yılların başına kadar olan döneme gelinceye değin bürokratik yapılarının değişmemesi yönünde tercihte bulunmuştur (Kalağan, 2010:145). Ancak 1980'li yılların ortalarından itibaren Türk kamu bürokrasisinin siyaset bilimi ve hukuktan iyice uzaklaşıp işletmecilik anlayışına doğru yönelmesi ile birlikte kamu yönetimi disiplininin varlı̆ğ tartışmalı bir hal almıştır. Bu durumda Türkiye'de kamu yönetimi disiplini ilgi merkezi haline gelmiş ve bu ilgiyi incelemeye yönelik terimler, kavramlar ve yöntemler gitgide belirsizleşerek etkisini yitirmeye başlamıştır (Acar ve Özgür, 2014:29).

Türk kamu bürokrasisinde kamu hizmetlerinin verimliliğini ve kalitesini arttırmaya yönelik çalışmaların hayata geçirilmesini ve bu konuda değişim yapılmasını gerektiren nedenler, dünyanın diğer ülkelerindeki kamu bürokrasisini etkileyen nedenlerden çokta farklı değildir (Kalağan, 2010:145). Bu ortamda, rekabetçi ve serbest piyasa koşullarının hâkim kılınması ve özelleştirmenin çeşitli şekilleri olmak üzere yeni kamu işletmeciliğini içeren pek çok kurumun uyguladığı yenilikler, Türk kamu bürokrasisinin birçok alanında da uygulanmaya başlamıştır (Acar ve Özgür, 2014:29). Bu bağlamda küreselleşmenin getirdiği "bireycilik, karlılık, esneklik, rekabetçilik, verimlilik" gibi girişimci karaktere ve özgürlükçü düşüncelere dayalı değerlerin yönetim düşüncesine hâkim olmasını sağlayacak toplumsal, ekonomik, kültürel ve siyasal değişim ölçütleri tüm dünyadaki kamu bürokrasilerini etkilediği gibi Türk kamu bürokrasisini de etkilemiştir. 
Yeni kamu işletmeciliği yaklaşımının Türk kamu bürokrasisine etkileri şu şekilde özetlenebilir:

- Sosyal refah devletinin arınması ve piyasa odaklı devlet anlayışı

- Deregülasyon ve özelleştirme uygulamaları

- Kamu hizmetlerinin özel sektöre ya da yarı bağımsız kamu kurum ve kuruluşlarına aktarılması

- Kamu bürokrasisinde yerel istihdam ve sözleşmeli personel uygulamaları

- Üst kurul tipi örgütlenme ve bağımsız idari otoriteler oluşturulması

- E- Devlet uygulamaları ve bilgi toplumu anlayışının benimsenmesi (Kalağan, 2010:145-147).

Bütün bu uygulamalar hemen hemen yarım asır boyunca yeni kamu işletmeciliği bağlamında ülkeler tarafından denenmiş ve ortaya çıkan bazı sorunlar nedeniyle bu düşüncenin yeniden gözden geçirilmesi gerektiği düşünülmüştür. Yeni kamu yönetimi anlayışıyla birlikte gelişmelerin sosyal boyutu ihmal ettiği anlaşılmış, özellikle vatandaşın müşteri gibi görülmesi düşüncesi en önemli eleştiri noktası haline gelmiştir (Çevik, 2012:22).

\subsection{Yeni Kamu İşletmeciliği Anlayışının Kamu Personel Yönetimine Etkileri}

Ülkemizde kamu personelini işe alma özelliklerine bakıldığı zaman, işin niteliklerine en uygun kişinin işe alınması ve adaletsiz bir alımın ortadan kaldırılması için merkezi sınav sistemi uygulanmaktadır. Fakat bu system de genel olarak bakıldığında doğru bir sistem gibi görünüyor olsa da, personel alımında beklenen sonucu vermemektedir. Çünkü bu sistemde, işe alınacak kamu personeli ile kamu personelinin alınacağı pozisyon arasında tam bir ahenk görülmemektedir. Her memurun almış olduğu eğitim ve edinmiş lduğu tecrübeye göre bir görevde bulunması gerekirken, ülkemizde bu memurların büyük çoğunluğunun alakasız görevlerde ve hizmetlerde kullanıldığı görülmektedir. Bu durum da, aynı işte çalışanların farklı ücret almasına, aşırı ve dengesiz şekilde dağıtılmış personel sayısına, kayırmacılığa ve liyakat sistemine gereken önemin verilmemesi gibi sorunlara sebebiyet vermektedir (Söylemiş, 2009:150). Bu sorunların baş göstermesi üzerine kamuda yeni bir personel yönetimi sistemi oluşturulması kaçınılmaz hale gelmiştir. Yeni kamu işletmeciliği anlayışı ise, yine bu durumu geleneksel kamu yönetimi anlayışını baz alarak açıklamaya çalışmıştır.

Yeni kamu işletmeciliği yaklaşımının kamu personel yönetimine etkileri şu şekilde sıralanmaktadır :

- Öncelikle personel yönetiminde bir lisan değişikliğine gidilmiş, "personel yönetimi"' yerine 'insan kaynakları yönetimi" kullanılmaya başlanmıştır. Bunun yanında yine personel yönetimi ile ilgili olarak performansla ilgili kavramların da sıkça kullanıldığı görülmektedir.

- Yeni kamu işletmeciliği ile birlikte "esneklik, sözleşmeli istihdam, bireysel sözleşme, değişim yönetimi" gibi personel yönetiminde sıkça kullanılan ve personel yönetiminin değişimine etki eden kavramların da ortaya çıktığı görülmektedir.

- Yeni kamu işletmeciliği ile birlikte istihdam şekillerinde değişiklik yapılmış, kamu personelinin işine son vermeyi kolaylaştırmak ve kamudaki personel sayısını azaltmak amaçlanmıştır. Dolayısıyla memur ücretlerinin içinde yer alan emeklilikve yan ödemeler ile ilgili ödemeler de azaltılarak, kamu personelinin maliyetinin düşürülmesi için gerekli yollar aranmıştır.

- Yeni kamu işletmeciliği anlayışı ile hemen hemen bütün kamu personelinin örgütsel performansa katkıları değerlendirmeye tabi tutulmaktadır. Buna da performansa dayalı ücret sistemi adı verilmektedir.

- Geleneksel anlayışın aksine işletmecilik anlayışında, kamu personelinin kurumlar arası geçişi mümkün olabilmektedir (Sözen, 2005:105-107). 


\section{TÜRK KAMU BÜROKRASISINDE PERSONEL REFORMU YAPILMASINI GEREKTIREN NEDENLER}

\subsection{Kayırmacilık}

Kayırmacılık, Türk kamu bürokrasisinin en önemli işlemsel sorunlarından birisidir (Kalağan, 2010:112). Maalesef ki Türk kamu bürokrasisinde bir taraftan işine layık, işinin gerektirdiği bilgi ve becerilere sahip olan kişilere yer verildiği gibi işine layık olmayan ve işinin gerektirdiği özelliklere sahip olmayan kişilere de yer verilmektedir (Yıldız, 2017:62). Kayırma sistemi, kamu kurumunda çalışan kamu görevlilerinin hem hizmete girerken hem de hizmette kalırken belli bir görüşe, etnik mezhebe, siyasal partiye, belli bir ekonomik zümreye bağl1lık ya da aidiyet ölçütüne göre dağıtılması anlamına gelmektedir (Ayman Güler, 2005:142). Bir nevi, kadrolara keyfi yerleştirme yapılmakta ve devlet memurluğu bir velinimet olarak görülmektedir (Yıldız, 2017:64).

Kayırma sisteminde, ülkemizde yıllarca kamu personeli olarak işe alınanlar çalışmış olduğu kurumun menfaatlerini düşünmek yerine, kendisini o pozisyona getirenlerin menfaatlerini koruma yoluna gitmişlerdir. Kayırmacılığın birçok çeşidi olmasına rağmen, bunlardan en az işleyeni hemşeri kayırmacıllı̆ı̆ır (Yıldız, 2017:64-67). Bunu önlemek adına kamu personel sisteminde kariyer sistemine karşıllk liyakat sistemi getirilmiştir (Ayman Güler, 2005:142). Liyakat, kamu hizmetleri görevine görevlerine girerken, ilerlerken ve sona erdirirken eşitlik ilkesine uygun davranılmasını gerektiren sisteme verilen addır (Yerli ve Çeçen, 2014:91). Türkiye'de kamu personeli olarak sayılan işçi, sözleşmeli ve geçici personel, memur bu ilkeye göre sınıflandırılmıştır. Liyakat ilkesiyle memuriyet görevine getirilecek kişilerin belli bir zümreden değil toplumun tüm kesiminden seçilmesi sağlanmıştır (Ayman Güler, 2005:143-144). Ancak Türk kamu bürokrasisinde liyakat üzerinde birç̧ok çalışmalar yapılmış ve fazla bir ilerleme sağlanamamıştır. Büyük çoğunlukla memurların görevde yükselmelerinde liyakatten ziyade kıdem esas alınmaktadır (TÜSİAD, 1983:32-33). Kayırmacılık sisteminin kamu personel sisteminde halen geçerli olduğunu söylemek mümkündür. Çünkü siyasi iktidarı ele geçiren her parti, gücünün yettiği yere kadar kadrolaşma yaratmakta ve kadroyu değiştirmekte, mümkün olduğunca kendi üstünlüğüyle atadığı kişilerle çalışmayı istemektedir (Şahin, 2011:204-205).

\subsection{Siyasallaşma}

Kamu yönetimi siyasal iktidarın bir yürütme aracı konumundadır (Y1lmaz ve Kılavuz, 2002:19). Kamu kurumlarında çalışacak kişilerin seçimine siyasi liderlerin karar vermesi, kendilerine hayranlık duyulmasını istemeleri artık günümüzde daha fazla olasılık haline gelmiştir (Hughes, 2014:182). Dolayısıyla siyasal iktidar gerçekleştirmek istediği politikaları daha verimli ve etkin gerçekleştirebilmek için bürokrasiye egemen olmaya çalışmaktadır (Acar, 2016:157). Eryılmaz'a göre siyasallaşma "kamu görevlerine yapılan atamalarda siyasi faktörlerin birinci derecede rol oynamasıdır" (Eryılmaz, 2010:253). Yani tanımla özdeşleştirmek gerekirse, memurluğa alımlarında ve memurların yükseltilmesinde siyasal iktidarın yapmış olduğu siyasi adam kayırmacılığıdır (Yılmaz ve Kılavuz, 2002:19).

Türk kamu bürokrasisinin hemen hemen bütün kurumları siyasallaşma sorunuyla yüz yüze gelmiş durumdadır (Yılmaz ve Kılavuz, 2002:20). Her iktidar değişikliğinde siyasi özellikte atamaların yapılması siyasallaşma olgusunun en büyük göstergesi olmuş ve bu toplumun her kesimi tarafından eleştirilen bir konu haline gelmiştir (Acar, 2016:157). Çünkü siyasal iktidarlar, yönetimde yaşanan siyasallaşmayı kolaylaştırabilmek adına yeni makamlar ve kadrolar oluşturmak çabasına girmektedirler (Eryılmaz, 2010:253). Türk kamu bürokrasisinin personel rejiminde en önemli özellik siyasi yönden tarafsızlık ve yeterlik olmasına rağmen, uygulamada bu görülmemiş ve siyasallaşma farklı yöntemler kullanılarak uygulanmaya devam etmiştir (Yılmaz ve Kılavuz, 2002:20). Memuriyet bazı dönemlerde neredeyse hükümete ve hükümeti oluşturan siyasi partilere bağımlı bir kurum haline gelmektedir. Bunun için de kamu personelinin kariyerinde yükselmede bilgi ve becerisini göstermekten ziyade iktidara ya da iktidara yakın bir partiyle yakın ilişki kurması zorunluluğu doğmaktadır (Eryılmaz, 2010:253). 


\subsection{Yolsuzluk ve Rüşvet}

Yolsuzluk ve rüşvet kamu bürokrasisinin en yaygın görülen işlemsel sorunlarından biridir (Yılmaz ve Kılavuz, 2002:20). Kamuda yolsuzluk, kamu personelinin yapılmaması gereken işlemleri yapması ya da yapılması gereken işlemleri hızlandırmak karşılığında çıkar sağlamasıdır (Eryılmaz, 2010:254). Yönetimde yozlaşmayı ifade eden rüşvet, çıkar sağlama, zimmete geçirme gibi ahlak ve hukuka ters düşen davranışların tümü yolsuzluğu ifade eder (Aydın, 2015:265). Yolsuzluğun maddi anlamda rüşvet dışında bir de dayanışma şeklinde türü vardır ve bu da yakın akrabaları kayırma şeklinde gerçekleşir (Yılmaz ve Kılavuz, 2002:21).

Türkiye'de kamu bürokrasisinde yolsuzluk sorununun hızlı bir değişim göstermesinde hızlı büyüyen nüfus artışı, gelir dağılımının adaletsiz olması, özellikle de kamu personelinin görev yetkilerinin çok geniş olması etkili olmuştur (Aydın, 2015:265-266). Türkiye'de yasalara rağmen yolsuzluk yaygın bir şekilde ilerlemiş, yönetimde merkeziyetçilik, aşırı kuralcılık ve bürokrasideki hantallık gibi durumlar rüşveti besleyen faktörler olmuştur (Eryılmaz, 2010:254).

Yolsuzluk ve rüşvet, Türk kamu bürokrasisinde alışkanlık ve hastalık haline gelmiş, bürokraside verimliliği etkileyen çok önemli bir unsur haline gelmiştir. Kamu personeli rüşvete destek veriyorsa, rüşveti almak için bahane arıyorsa, bürokratik eylem ve işlemlerde denetim gereğinden fazla yapılmıyorsa rüşvetin yapılması için gerekli ortam sağlanmış demektir. Maddi ya da manevi şekilde bu işin yapan açgözlülük peşinde koşan kamu görevlileri, kamu bürokrasisinin yozlaşmasına neden olmuştur (Yılmaz ve Kılavuz, 2002:21-24). Yolsuzluğun engellenmesi ya da önüne geçilebilmesi için kamu çalışanları için önemli yaptırımlar sağlanmalı ve kamu personelinin sorumluluğu arttırılmalıdır (Aydın, 2015:266).

\subsection{Kuralcılık ve Sorumluluktan Kaçma}

Her kurum, çalışmalarını kendi örgütleri içerisinde salt geçerliliğe sahip yazılı kurallara uygun olarak yürütmekte, çalışanlarından örgütün amaçlarını gerçekleştirmek amacını taşımalarını ve buna uygun bir davranış göstermelerini beklemektedir. Ancak kurumlarda bu kurallara uyulmaması zaman zaman birçok sorunu beraberinde getirmektedir (Akçakaya, 2016:687).

Kuralcılık, genellikle yasaların detaylı bir şekilde hazırlanması ve düzenlenmesi, yöneticilerin de bu sorunlar ve olaylar karşısında bir öncelik kullanmamasının sonucunda meydana gelen bir üründür (Eryılmaz, 2010:252). Kamu bürokrasisinde kuralcılığın ortaya çıkmasının bazı nedenleri bulunmaktadır (Akçakaya, 2016:687). Ya kurallar detaylı şekilde belirlenmiş personele takdir yetkisi verilmemiştir (Eryılmaz, 2010:252), ya yasama organı bürokrasiyi kendi istekleri doğrultusunda işletmek istemiştir ya da kurumun başında bulunan yönetici kamuda çalışan kişilerin zarar görmelerini engellemek istemiş, vatandaşın gözetiminden ve kontrolünden uzak tutmak istemiştir (Akçakaya, 2016:687). Çünkü bürokraside, kurumun başında bulunan yöneticinin sorumluluğu, hizmetleri verimli bir şekilde yürütüp yürütmemesine bağlı olarak değil, yapılan işlemlerin kurallara uygun bir şekilde yapılıp yapılmadığına göre değerlendirilir (Eryılmaz, 2010:252).

Türkiye'de kamu hizmetlerinin sunulması çok detaylı kurallara bağlanmıştır. Kuralların çok detaylı olması bürokrasinin işleyişini çok yavaşlatmakta ve kamu personeli için bir bahane kaynağı oluşturmakta ve yöneticinin yetkilerini kötüye kullanmasına neden olmaktadır (Yılmaz ve Kılavuz, 2002:21). Birçok kural, iş yapmaktan ve sorumluluktan kaçan yöneticiler için bir firsat olarak görülmektedir. Dolayısıyla kamu görevlileri bir sorunla uğraşmak istemedikleri zaman keyfi davranışlarda bulunabilmektedirler (Eryılmaz, 2010:252). 


\section{YENI KAMU ISŞLTMECİLIĞİ ANLAYIŞINA GÖRE TÜRK KAMU BÜROKRASİSINDE YAPILAN PERSONEL REFORM ÇALIŞMALARI}

\subsection{Memurluk Statüsünün Esnekleştirilmesi}

"Memur" kelimesi Arapça kökenli bir kelime olup, "işyar" anlamına gelmektedir. Memur kelimesi, yine Arapça bir kelime olan "emr" kökünden türemiş olup, "devlet hizmetinde aylıkla çalışan kimse, görevli, yükümlü" anlamina da gelmektedir (Kayar, 2015:35).

Devlet Memurları Kanunu'na göre bir kimsenin memur sayılabilmesi için (Akgüner, 2014:49);

- "Devlette ya da öteki kamu tüzelkişiliklerinde ya da bunların denetim ve gözetimi altında kurulan ve çalışan bir birimde"

- "Genel idare esaslarina göre"

- "Asli ve sürekli kamu hizmetlerini sürdürmek için" görevlendirilmiş olmaları gerekmektedir.

1924 Anayasası ve Memurin Kanunu memur hususunda 1876 Kanuni Esasi ile çok benzerlik göstermekte ve bu kanunda "siyasal haklara sahip olan her Türk, ehliyet ve hak kazanmasl durumuna göre memur istihdam olunabilirler", ibaresi yer almaktadır.

1982 Anayasası döneminde 657 sayılı kanunun 4. Maddesine göre ise memur tanımı:

"Mevcut kuruluş biçimine bakılmaksızın, Devlet ve diğer kamu tüzelkişiliklerince genel idare esaslarına göre yürütülen asli ve sürekli kamu hizmetlerini ifa ile görevlendirilenler" olarak yapılmıştır (Kayar, 2015:35-37).

1980 sonrasında kamu personel düzeni, devletin küçültülmesi ile ilgili ortaya çıkan tartışmalardan ve dünyada yaşanan neoliberal politikalardan oldukça etkilenmiştir. 1982 Anayasasında halk oyuna sunularak kabul edilmiş olan memurluk statüsünün temel istihdam biçimi sayılmasına karşın, özellikle kanun hükmünde kararnamelerde (KHK) sözleşmeli personel statüsü teşvik edilmeye başlanmıştır (Kayar, 2011:31).

Türk kamu bürokrasisinde kamu görevlileri alanında büyük karışıklık yaşanmış, Cumhuriyet döneminde eskiye nazaran bir düzen getirilmiş ve memurluk bir meslek haline getirilmiştir (Gözübüyük, 2013:8). Toplam kalite yönetiminin tekniklerinden ve yöntemlerinden yararlanılması, geçici, kısmi zamanlı ve sözleşmeli istihdamın esas alınması, bazı kamu hizmetlerinin dış faktörler yoluyla başka firmalara ya da kurumlara gördürülmesi, eşit işe eşit ücret ve performans sisteminin getirilmesi bu doğrultuda yapılan düzenlemeler arasında yapılmaktadır (Nohutçu ve Balc1, 2005:175).

Küreselleşen dünyada yönetimin rekabet edebilmesi, büyük bir hızla değişen koşullara ayak uydurabilmesi, işletmelerde uygulanan yöntemlerin kamuya aktarılabilmesi, verimli ve etkin çalışabilmesi yönetimin sadece esnek bir örgüt yapısına sahip olabilmesiyle mümkündür. Bunun sonucunda doğal olarak esnek bir örgüt yapısı, kamu çalışanlarının da esnekliğini zorunlu hale getirmektedir. Özel sektörde uygulama alanı bulan ve kamuda da kullanılmaya başlayan esneklik anlayışı personel reformunu da büyük ölçüde etkilemiş, performansa bağlı olarak ücretlerin değişmesine olanak veren istihdam şekillerinin ve performansa dayalı ücret sistemlerinin kabul edilmesinde etkili olmuştur (Turan, 2015:166-168).

Bir kamu görevlisi sayılan memur, kamu kurum ve kuruluşlarında sürekli ve asli olarak kamusal mal ve hizmetleri kamu aleyhine üreten, sorumlulukları ve yetkileri ile yükümlülükleri ve yasakları kanunlarda ve anayasada belirtilen kişilerdir (Kartal, 2011:227).

Türkiye'de memurluk makamının esnekleştirilmesi birkaç koldan birlikte ilerlemektedir. İlk önce memur istihdamı azaltılmakta, memurluk düzeninin içi boşaltılmakta ve düzenin içyapıları esnekleştirilmektedir. Üst Düzey bürokraside, memurluk makamının eritilmesi kadro karşılığı sözleşmeli ya da sözleşmeli konumlar eliyle, alt düzey bürokraside ise geçici işçiler ve taşeronlaşma aracıllğıyla yürütülmektedir. Memur istihdamının daraltılması özellikle KİT'lerde ve yerel yönetimlerde ortaya çıkmıştır (Aslan, 2012:481-482). Bu daraltma da sayısal esneklik kullanılarak yapılmış ve personel sayısı oldukça azaltılmıştır (Taner Köroğlu, 2010:147). 1980 sonrasında yaygınlaşan memurluk statüsünün içinin boşaltılması rejimi de maaşlarda ortaya çıkan büyük bir düşüş ve maaş rejiminde ortaya çıkan eşitsizlik sebebiyle görülmüştür. Taşeronlaşma Yardımcı Hizmetler Sınıfında 1988 yılında başlamış, 2000'li yıllarda ise "Teknik Hizmetler" ve "Sağlık ve Yardımcı Sağlık Hizmetleri" sınıfları olmak üzere memurluk rejiminde yaygınlaşmaya başlamıştır (Aslan, 2012:483-490). 
Esneklik anlayışı ile memur statüsü çekirdek işgücünü oluştururken, rutin işlerle görevli olan ve taşeronlaştırılan geçici işçilerde çevre işgücünü oluşturmuşlardır (Taner Köroğlu, 2010:148).

\subsubsection{Sözleşmeli Personel Çalışmaları}

Sözleşmeli personel statüsü, 1980'li yıllardan beri kamu bürokrasisinde esnek kamu personel rejiminin temel istihdam biçimi olma özelliğini kazanmış ve kamuda memurluk statüsünü çözmüştür (Aslan, 2012:502). Genel olarak sözleşmeli personel, işçi ve memur statüsünde olmayan kamu görevlisidir, belirli sürelerle yenilenen sözleşmelere göre ve memurlar için geçerli olan süre kadar çalışırlar. Sözleşmeli personel istisnai ve geçici süreliğine bir çalıştırma şekli olduğu için, belirli bir yönteme ve biçime göre işe alınabilirler. Devlet Memuru Kanunu'na göre bir kimsenin sözleşmeli personel sayılabilmesi için geçici personel olma şartı aranmamaktadır (Akgüner, 2014:51). Sözleşmeli personel olmak isteyen kişilerin özel ve genel koşulları taşımaları, açılacak olan sinav1 kazanmaları gerekmektedir (Kayar, 2010:45).

\subsubsection{657 Sayılı Yasa Çerçevesinde Sözleşmeli Personel İstihdamı}

1982 Anayasasında sözleşmeli personelle alakalı herhangi bir düzenleme bulunmamaktadır ve bu sorun sözleşmeli personelin memur statüsünde olmadığı için "diğer kamu görevlileri" kapsamına girmesinden kaynaklanmaktadır (Akgüner, 2001:40). Sözleşmeli personel ile alakalı olarak yapılan ilk çalışma 657 Devlet Memurları Kanunu'dur (Şinik, 2011:164).

657 Devlet Memuru Kanununun 4. Maddesinin b bendine göre sözleşmeli personel;

"Kalkınma planı, yıllık program ve iş programlarında yer alan önemli projelerin hazırlanması, gerçekleştirilmesi, işletilmesi ve işlerliği için şart olan, zaruri ve istisnai hallere münhasır olmak üzere özel bir meslek bilgisine ve ihtisasina ihtiyaç gösteren geçici işlerde, kurumun teklifi üzerine Devlet Personel Dairesi ve Maliye Bakanlığının görüşleri alınarak Bakanlar kurulunca geçici olarak sözleşme ile çalıștırılmasına karar verilen ve işçi sayılmayan kamu hizmeti görevlileridir" (Ayman Güler, 2005:117).

\subsubsection{KİT’lerde Sözleşmeli Personel İstihdamı}

Türkiye'de kamu bürokrasisinde istihdam edilen sözleşmeleri personellerin büyük bir bölümü Kamu İktisadi Teşebbüslerinde (KİT)'lerde toplanmıştır (Ayman Güler, 2005:118). Asli ve sürekli kamu hizmetlerinin memurlar eliyle görülmesi ilkesi göz ardı edilmiş ve bu tür hizmetler memur tanımına girmeyen işçi ve sözleşmeli personel eliyle yürütülür hale gelmiştir. KİT’lerdeki memur sayısı sözleşmeli personel uygulamasıyla hızla eritilmiştir. 1985 yılında toplam KİT personeli içinde memurların oranı \%40, sözleşmeli personel oranı \%0,1'dir. KİT'lerde memurların oranı 1989'da \%12,9'a, 1996'da \%3,7'ye gerilerken, aynı yıllarda sözleşmeli personel oranı önce \%31,7’ye sonra da \%41,7'ye yükselmiştir (Sezen, 2003:10-11).

KİT'lerde memurluk rejiminin çözülmesi, KİT'lerdeki özelleştirme süreci için anahtar rol oynamıştır. KİT'lerde memurluk istihdamının kırılması, 1990'larda özelleştirme ve tasfiye sürecinin sorunsuz ilerlemesinin kapısını açmıştır. Ayrıca taşeronlaşma da KITT'lerde görülen eğilimler haline gelmiştir (Aslan, 2012:568).

\subsubsection{Sağlık Bakanlığı’nda Sözleşmeli Personel Uygulaması}

Sağlık hizmetleri alanında 2003 yılında başlayan süreç, sözleşmeli personel çalıştırma ve taşeronlaşmanın bakanlıklarda asli ve sürekli hizmetlere sıçramasının açık örneğini oluşturur (Aslan, 2012:541). Sağlık bakanlığında sözleşmeli personel istihdamının yaygınlaştırılması, bu hizmeti son derece esnek ve parçalı bir yapıya büründürmüştür (Sayan ve Küçük, 2012:174-175).

2005 yılında yayımlanan 5413 sayılı kanun ile sağlık personeli istihdamında yeni bir statü getirilmiştir. Söz konusu kanunla;

"kadrolu istihdamın mümkün olmadı̆̆ hallerde, ücretleri döner sermayeden karşılanmak kaydiyla 657 sayılı Devlet Memurları Kanununun 36'ncı maddesinde belirtilen sağllk hizmetleri ve yardımcı sağllk hizmetleri sinıfindaki unvanlarda çalıştırllmak üzere merkezi sınav sonuçlarına göre 657 sayılı Kanunun 4'üncü maddesinin (B) fikrasına tabi sözleşmeli personel çalıştırılabileceği",

öngörülmüştür (Sayan ve Küçük, 2012:180-181). Getirilen bu yasa ile Sağlık Bakanlığında memurluk statüsü sözleşmeli personel eliyle çözülmüştür. Sağlık bakanlığında sözleşmeli personel alımı diğer sözleşmeli personel alımlarından farklı olarak uzman doktor, doktor, diş doktoru ve eczacı pozisyonlarını kura ile diğerleri ise merkezi sınav ile yapılmaktadır. Ayrıca ataması yapılan sözleşmeli personelin mali yılı kapsayan birer yıllık sözleşmeyle istihdam edilme esası getirilmiştir (Aslan, 2012:543-547). 


\subsubsection{Geçici Personel Çalışmaları}

Bir yıldan az süreli veya mevsimlik hizmet olduğunda Devlet Personel Başkanlığı ve Maliye Bakanlığının görüşlerine dayanılarak Bakanlar kurulunca karar verilen görevlerde ve belirtilen ücret ve adet sınırları içinde sözleşme ile çalıştırılan ve işçi sayılmayan kimselerdir (Şinik, 2011:165).

Geçici personeller esnekliğin yerel yönetimlerdeki kaynă̆ıdır. Kamu idareleri sürekli işçileri işe alırken belirli bir sınav koşulu bulundurmakta, geçici personel alırken herhangi bir sınav koşuluna tabi tutmamaktadır. Belediyelerde memurluğu çözme mekanizması geçici personel istihdamının yaygınlaşması ile ortaya çıkmıştır. Hatta dönem dönem belediyelerde geçici personel istihdamı diğer istihdam şekillerinin oldukça önüne geçmiştir (Aslan, 2012:574-582).

\subsubsection{Taşeron Personel Çalışmaları}

Taşeron personel, kadro ve pozisyonları işgal etmeden kamu kurumlarında kamu hizmetlerini yerine getiren kamu personel rejiminin asli bir kişisidir (Aslan, 2012:584). Taşeronlaştırma, bir iş yerinde üretilen mal ve hizmetlerin belli bir iş sözleşmesi karşılığında alt işverenlere verilmesidir. Taşeron işverenin istihdam ettiği işçiye taşeron işçi denir (Kaya, 2015:258-259).

Ülkemizde taşeron işçi çalışmalara çok eskilere dayanmaktadır ve yakın bir geçmişe de karşılık gelmektedir (Kaya, 2015:259). Bu çalışmalar, kamu personel rejiminin en dıştaki halkasını oluşturmaktadır (Aslan, 2012:584). Türkiye' de ve dünyada hızla yayılan bu istihdam şekli çalışma yaşamında korkunç gerçekleri ortaya çıkarmış ve git gide yaygınlaşmıştır (Kaya, 2015:259).

\section{SONUÇ}

Ülkemizde son yıllarda yönetim anlayışında büyük sorunlar yaşanmakta ve bu sorunlardan büyük oranda kamu personel yönetimi de etkilenmektedir. Kamu personel rejiminde yapılan değişikler sorunları çözememekte yeni çözümler bulunmasını gerektirmektedir.

Literatüre bakıldığı zaman kamu personelinin gerek yönetsel gerekse işlemsel birçok sorunlarının bulunduğu görülmektedir. Ancak kamu personeli kamunun işlemsel sorunlarını çözmekteki en önemli faktördür. Geleneksel yönetim anlayışının getirdiği bazı işlemsel sorunları çözmek amacıyla kamuda işletmecilik anlayışı uygulanmaya başlamış, ancak tam olarak bu anlayış biçimi de sorunları çözmeye yetmemiştir. Kamuda bir tek memurluk makamına karşılık sözleşmeli personel, geçici personel ve taşeron işçileri istihdamı uygulanmaya başlamış ve kamu bürokrasisinde hizmette verimliliğin ve etkinliğin arttırılması amaçlanmıştır. Ancak yeni kamu işletmeciliği anlayışı ile birlikte ortaya çıkan bu istihdam şekilleri de sorunların çözümünde yeterli etkiyi gösterememiştir.

Geleneksel kamu yönetimi anlayışı bağlamında memurluk bir meslek olarak görülmüş ve yeni kamu işletmeciliği anlayışı ile geleneksel yönetimin katı kuralcılığına karşı çıkılarak memurluğa esneklik getirilmiştir. Artık kamu bürokrasisinde personel yönetimi yerine insan kaynakları yönetimi kullanılmaya ve vatandaş müşteri gibi görülmeye başlanmıştır. Vatandaşın müşteri gibi görülmesi son dönemlerde büyük eleştirilere maruz kalmış, işletmecilik anlayışının kendisini gözden geçirmesi gerekliliğini vurgulamıştır. Memurluğa getirilen esneklik anlayışına bağlı olarak sözleşmeli personel istihdamı getirilmiş ve bu istihdam memurluk statüsünün kırılmasına neden olmuştur. Devlet memurlarının sözleşmeli personel statüsüne getirilmesi büyük sorunları beraberinde getirmiştir. Memurun aynı işi yapmalarına rağmen sözleşmeli personel ile aynı haklara sahip olması motivasyonunun ve veriminin düşmesine yol açmıştır. Dolayısıyla sözleşmeli istihdam sisteminin getirişmesiyle yeni kamu işletmeciliğinin bir gereği olan verimliliğin ve etkinliğin arttırılması hedefi birbirine ters düşmüştür.

Yeni kamu işletmeciliği anlayışının getirmiş olduğu İnsan kaynakları yönetimi kamuda esnekliğin en önemli göstergesidir. Ancak Türkiye'de insan kaynakları yönetimi uygulanıyormuş gibi görünse de tam manasıyla insan kaynakları yönetimine geçiş sağlanamamıştır. Çünkü bu yönetim şeklini uygulamak personel seçiminde tarafsızlığı, eşitliği, liyakat ilkesini, adil ücreti ve güvenceyi gerektirmektedir. Türkiye'de ise personel seçiminde bu ilkeler tam olarak gerçekleştirilmemekte, ancak kamu hizmetleri yürütülmeye devam etmektedir.

Yeni kamu işletmeciliği ile beraber kendisine daha geniş uygulama imkanı bulan taşeron işçi uygulamalarında da devletin amacı kar elde etmek olmuştur ve bu istihdamı büyük ölçüde yaygınlaştırma çabasına girmiştir. 
Ancak yakın zamanlarda görülmüştür ki kamu kurum ve kuruluşlarında taşeron işçi istihdamı devleti kar elde etmek yerine zarara sürüklemiştir. Bu durumdan tek kazanç sağlayan ise işletmeler yani alt işverenler olmuştur. Türkiye'de son dönemlere bakıldığı zaman yeni kamu işletmeciliği anlayışının yanlış uygulandığını gösteren en önemli sorunun taşeron işçi istihdamı olduğu anlaşılmış ve bu sisteme yeni model çözüm üretilmeye çalışılmıştır. Taşeron işçilerin yıllardır memur ve sözleşmeli personelle aynı işi yapmasına ve aynı şartlarda çalışmasına rağmen kadrolu çalışanların haklarından faydalanamaması Türk kamu bürokrasisini harekete geçirmiştir. Son dönemlerde taşeron işçilerin sürekli işçi kadrosuna alınması konusunda büyük adımlar atılmış, bir kısmı sürekli işçi konumuna getirilmiş ve bir kısmının da sürekli iş̧̧i kadrosuna geçiş işlemleriyle ilgili sorunların devam ettiği görülmektedir. Cumhurbaşkanlığı hükümet sistemiyle birlikte il özel idarelerinde ve belediyelerde kadrosuz memur çalıştırılamayacağı hususu getirilmiştir. Genel olarak ortaokul mezunu olan kimselerin memur olarak atanabileceği, eğer ortaokul mezunu kimselerin memur olma istekleri olmazsa ilkokul mezunlarının bile memur olarak atanmasının uygun olabileceği kararı alınmıştır. Yine 2018 yılı içerisinde yapılan düzenlemeyle sözleşmeli personelin sendikalı olabileceği hükmü getirilmiştir.

Görülüyor ki, yeni kamu işletmeciliği anlayışı ile birlikte yaşanan gelişmeler kamu personel yönetiminde ve istihdam şekillerinde köklü bir yenilik getirmemiştir. Gelişmiş ve az gelişmiş ülkeler işletmecilik anlayışını çok kolay kabullenip uygulamaya geçseler de Türk toplumu geleneksel anlayıştan büyük bir kopuş yaşamamıştır. Günümüzde devlet halen en büyük işveren konumundadır. Atamalar, mülakatlar hala devlet tarafindan yapılmakta, insan kaynakları yönetimi gereği gibi uygulanmamakta ve bu durumda işletmecilik anlayışı geri planda kalmaktadır. Atamalarda ve işe alımlarda işletmecilik anlayışının gereği olarak liyakat sisteminin çok ön planda tutulmadığı görülmekte, bilgi ve birikime bakılmaksızın kayırmacılığa dayalı subjektif değerlendirmeler hala devam etmektedir.

Sonuç olarak baktığımızda, Türk kamu bürokrasisinde işletmecilik anlayışından geleneksel anlayışa doğru bir geri dönüş yaşanmakta ve hatta geleneksel kamu yönetimi anlayışından büyük bir kopmanın yaşanmadığ 1 görülmektedir. Her ne kadar gelişmiş ya da az gelişmiş dünya ülkelerinde işletmecilik anlayışı kabullenilmiş ve yaygın bir şekilde ilerlemiş olsa da Türk toplumun geleneklerine, öteden beri alışılmış olduğu kültürüne ayak uyduramamıştır. Kamu personeline esneklik uygulamasının getirilmesi bazı olumlu sonuçlar doğruyormuş gibi görünse de, sorunların ortaya çıkmasına sebebiyet vermektedir. Yolsuzluk, kayırmacılık ve siyasallaşma günümüzde halen kısmen de olsa devam etmekte, memurluğun yanında getirilen istihdam biçimleri bu sorunlara çözüm getirememekte ve bunlara daha caydırıcı çözümler üretilerek önünün kesilmesi gerekmektedir. Türk kamu personel sürecinde ve istihdam şekillerinde yaşanan bu olumsuzluklar yeniden gözden geçirilmeli, daha net ve toplumun benimsemekte zorluk çekmeyeceği bir değişim ve yenilik getirilmelidir.

\section{KAYNAKÇA}

ACAR, Eray (2016), "Dünyada ve Türkiye'de İdareyi Değişime İten Nedenler", Dumlupınar Üniversitesi Sosyal Bilimler Dergisi, S.20(Afro-Avrasya Özel Sayıs1), ss.147-159.

AKÇAKAYA, Murat (2016), "Bürokrasi Kuramlarl ve Türk Kamu Yönetiminde Bürokratik Sorunlar", Gazi Üniversitesi İktisadi ve İdari Bilimler Fakültesi Dergisi, S.18(3), ss.669-694.

AKGÜNER, Tayfun (2001), Kamu Personel Yönetimi, Der Yayınları, İstanbul, 4. Basım.

AKGÜNER, Tayfun (2014), Kamu Personel Yönetimi, Der Yayınları, İstanbul, 6. Basım.

AL, Hamza (2002), Bilgi Toplumu ve Kamu Yönetiminde Paradigma Değişimi, Bilim Adamı Yayınları, Ankara.

ASLAN, Onur Ender (2012), Devlet Bürokrasi ve Kamu Personel Rejimi, İmge Yayınları, Ankara, 2. Bask1.

AYDIN, Ahmet Hamdi (2012), Kamu Yönetimine Giriş, Seçkin Yayıncılık, Ankara.

AYDIN, Ahmet Hamdi (2015), Türk Kamu Yönetimi, Seçkin Yayınc1lık, Ankara.

BAŞ, Ümmügül (2009), 'Kamu Yönetiminin Temel Sorunları', Kamu ve Özel Kesim Yapısı ve İlişkileri (Ed. Tarık Söylemiş), Lisans Yayıncılık, İstanbul.

BİLGIÇ, Veysel (2003), "Yeni Kamu Yönetimi Anlayışı", Kamu Yönetiminde Çağdaş Yaklaşımlar (Ed. Asım Balcı, Ahmet Nohutçu, Namık Kemal Öztürk, Bayram Coşkun), Seçkin Yayıncılık, Ankara, ss.25-38. 
BİLGiN, Kamil Ufuk (2011), "Insan Kaynakları Yönetimi ve Türk Kamu Personel Sistemi’, Türkiye'de Kamu Yönetimi ve Kamu Politikaları (Ed. Filiz Kartal), Türkiye ve Orta Doğu Amme İdaresi Enstitüsü Yayınları, Ankara, ss.221-240.

BOZLAĞAN, Recep (2008), 'Geleneksel Kamu Yönetimi Yaklaşımı, Yeni Kamu Yönetimi Yaklaşımı ve Yerel Yönetimlere Etkileri', Türkiye'de Yerel Yönetimler (Ed. Recep Bozlağan ve Yüksel Demirkaya), Nobel Yayınc1lik, Ankara.

CAN, Halil- KAVUNCUBAŞI, Şahin- YILDIRIM, Selami (2009), Kamu ve Özel Kesimde İnsan Kaynakları Yönetimi, Siyasal Yayın Dağıtım, Ankara.

ÇEVIKK, Hasan Hüseyin (2012), Kamu Yönetimi, Seçkin Yayıncılık, Ankara, 2. Baskı.

ÇEVIKBAŞ, Rafet (2012), 'Yeni Kamu Yönetimi Anlayışı ve Türkiye Uygulamaları’, Ekonomi ve Yönetim Araştırmaları Dergisi, C.1, S.2, ss.9-32.

ERIÇOK, Recep Emre (2011), "Küresel Kriz Sonrasında Kamu Yönetiminde Anlayış Değişimi'", Küreselleşme ve Kamu Yönetiminde Dönüşüm (Ed. Ahmet Kesik ve Hasan Canpolat), Seçkin Yayıncılık, Ankara, ss.157-172.

EROĞLU, Hacer Tuğba (2010), "Yeni Kamu Yönetimi Anlayışının Türk Kamu Personeli Yönetimine Etkisi", Zonguldak Karaelmas Üniversitesi Sosyal Bilimler Dergisi, S.12, ss.225-233.

ERYILMAZ, Bilal (2010), Kamu Yönetimi, Okutman Yayınc1l1k, Ankara, 3. Bask1.

GÖZÜBÜYÜK, A. Şeref (2013), Türkiye'nin Yönetim Yapısı, Turhan Kitabevi, Ankara, 12. Basım.

GÜLER, Birgül Ayman (2005), Kamu Personeli, İmge Yayınları, Ankara.

GÜLER, Birgül Ayman (2005), Kamu Personeli Sistem ve Yönetim, İmge Kitabevi, Ankara.

HUGHES, Owen E. (2014), Kamu İşletmeciliği ve Yönetimi, Bing Bang Yayınları, Ankara.

KALAĞAN, Gökhan (2010), Türkiye’de 1980 Sonrası Bürokratik Dönüşüm, Beta Yayıncılık, İstanbul.

KAPUCU, Naim (2012), "Sivil Toplumun Kamu Politikalarına Etkin Katılımı: Yeni Kamu İşletmeciliğinden Yönetişime Geçiş ve Devlet- Birey Illişkileri", Yönetişim ve Yönetim Ekseninde Kamu Yönetimi (Ed. Fatma Neval Genç), Ekin Yayınc1lık, Bursa, ss.31-47.

KAYA, Gazanfer (2015), "Kamudaki Taşeron İşçileri Üzerine Bir Alan Araştırması: Adıyaman Örneği", Elektronik Sosyal Bilimler Dergisi, S.14(55), ss.257-267.

KAYAR, Nihat (2010), Kamu Personel Yönetimi, Ekin Yayınları, Bursa, 2. Bask1.

KAYAR, Nihat (2011), Kamu Personel Yönetimi, Ekin Yayınları, Bursa, 3.Baskı

KAYAR, Nihat (2015), Kamu Personel Yönetimi, Ekin Yayınları, Bursa, 6. Bask1.

ÖMÜRGÖNÜLŞEN, Uğur (2014), "Kamu Sektörünün Yönetimi Sorununa Yeni Bir Yaklaşım: Yeni Kamu İşletmeciliği", Çağdaş Kamu Yönetimi-1 (Ed. Muhittin Acar ve Hüseyin Özgür), Nobel Yayınc1lık, Ankara, 2. Basım, ss.3-44.

ÖZER, Mehmet Akif (2005), Yeni Kamu Yönetimi Teoriden Uygulamaya, Platin Yayınları, Ankara.

ÖZKAL SAYAN, İpek ve KÜÇÜK, Aziz (2012), "Türkiye'de Kamu Personeli İstihdamında Dönüşüm: Sağllk Bakanlığı Örneği", Ankara Üniversitesi SBF Dergisi, S.67(1), ss.171-203.

PARLAK, Bekir (2011), Kamu Yönetiminde Yeni Vizyonlar, Alfa Yayınc1lk, Bursa, 2. Bask1.

PARLAK, Bekir ve SOBACI, Mehmet Zahid (2008), Kamu Yönetimi, Alfa Aktüel Yayınları, Bursa, 2. Bask1.

SARAN, Ulvi (2005), "Kamu Yönetiminde Performans Sorunları ve Türk Kamu Personel Rejiminde Gelişmeler", Bilgi Çağında Türk Kamu Yönetiminin Yeniden Yapılandırılması-2 (Ed. Ahmet Nohutçu ve Asım Balc1), Beta Yayıncıl1k, İstanbul, ss.173-188.

SEZEN, Seriye (2003), Türk Kamu Yönetiminde Kurullar: Geleneksel Yapılanmadan Kopuş, TODAİE Yayınları, Ankara.

SOBACI, Mehmet Zahid (2014), İdari Reform ve Politika Transferi, Dora Yayıncılık, Bursa, 2. Basım. 
SÖZEN, Süleyman (2005), Teori ve Uygulamada Yeni Kamu Yönetimi, Seçkin Yayıncılık, Ankara.

ŞAHİN, Yusuf (2011), Yönetim Bilimi ve Türk Kamu Yönetimi, Murathan Yayınevi, Trabzon, 3. Bask1.

ŞİNIK, Bilal (2011), Türkiye'nin Yönetim Yapısı ve Kamu Personeli Ders Notları, Türkmen Kitabevi, İstanbul.

TANER KÖROĞLU, Özlem (2010), "Türkiye'de Personel Yönetiminden İnsan Kaynaklarına Geçişte Esneklik ve Memur Statüsü", Türk İdare Dergisi, S.469, ss.139-164.

TDK, http://www.tdk.gov.tr/ (Erişim Tarihi: 21.11.2018).

TURAN, Erol (2015), Kamu Yönetiminde Reform, Palet Yayınları, Konya.

TURAN, Erol ve ŞAHIN, Mustafa Yaşar (2016), 'Yönetim ve Kamu Yönetiminin Genel Nitelikleri", Kamu Yönetimi Temel Kavramlar (Ed. Erol Turan), Palet Yayınları, Konya.

TUTUM, Cahit (1979), Personel Yönetimi, TODAİE Yayınları, Ankara, 2. Basım.

TÜSİAD (1983), Kamu Bürokrasisi, TÜSİAD Yayını, İstanbul.

YALÇIN, A. Selçuk (2002), Personel Yönetimi, Beta Yayıncılık, İstanbul, 7. Basım.

YERLİ, Emre ve ÇEÇEN, Ekrem (2014), Kamu Yönetimi (Ed. Yasin Çoban), On İki Levha Yayıncılık, İstanbul, 2. Bask1.

YILDIZ, Günay (2017), "Kayırmacılık Olgusunun Türk Kamu Yönetimine Yansımaları", Akdeniz Üniversitesi Sosyal Bilimler Enstitüsü Dergisi, S.2, ss.62-76.

YILMAZ, Abdullah ve KILAVUZ, Raci (2002), "Türk Kamu Bürokrasisinin İşlemsel Sorunları Üzerine Notlar", Cumhuriyet Üniversitesi İktisadi ve İdari Bilimler Dergisi, S.3(2), ss.17-31. 